\title{
Exploring Strategies For Financial Resource Mobilization In Public Secondary Schools In Kapenguria Constituency West Pokot County Kenya.
}

\author{
Millicent Cherotich, Rose Atoni, Jennifer Munyua jmunyua \\ DOI: 10.29322/IJSRP.10.10.2020.p10623 \\ http://dx.doi.org/10.29322/IJSRP.10.10.2020.p10623
}

\begin{abstract}
In light of the one hundred percent transition from primary to secondary schools, greater investment of resources in education is key. However, the present state of most secondary schools in Kenya is quite deplorable. Some of the books in the library are obsolete, inadequate equipment in the laboratory and buildings overdue for renovation are some of the indicators that the schools have a financial challenge. The sstudy explored strategies for financial resource mobilization in public secondary schools in Kapenguria Constituency West Pokot County Kenya. The study was guided by the following research questions; To what extent is school fees payment as a form of financial resource mobilization effective among secondary schools in Kapenguria Constituency, West Pokot County, Kenya? To what extent has government financial intervention assisted schools as a form of financial resource mobilization among secondary schools in Kapenguria Constituency, West Pokot County, Kenya? To what extent is communityresources as a form of financial resource mobilization effective among secondary schools in Kapenguria Constituency, West Pokot County, Kenya? and to what extent have income generating activities assisted schools as a form of financial resource mobilization among secondary schools in Kapenguria Constituency, West Pokot County, Kenya? The study was guided by the financial agency theory and adopted the cross sectional survey design. The target population was composed of principals and Board of Management chairpersons. A Questionnaire was used to collect data. Quantitative data was analyzed using percentages and frequencies The finding were that schools to a large extent relied on school fees payment as a financial resource mobilization strategy. Other resource mobilization strategies were income generating activities and donations from the community. It was recommended that awareness campaigns should be held by the Ministry of Education, Science and Technology to sensitize parents on the importance of paying school fees on time and that The Ministry of education should allocate more funds to constituencies so as to enable needy students benefit from bursaries.
\end{abstract}

Index Terms- Exploring; Strategies; Financial Resource Mobilization.

\section{INTRODUCTION}

$\mathrm{E}^{\mathrm{d}}$ ducation remains the main catalyst for development in any society whether in the developed or developing world. The future development of the world and individual nations hinge more than ever on the capacity of individuals and countries to acquire, adopt and advance knowledge (Emana, 2019). In addition, efficient management of schools resources is crucial in order to make the school a pleasant, safe and comfortable center that will increase students attendance, motivation and willingness to participate adequately in both curricula and co-curricular activities (Amos \& Koda, 2018).

A school itself is an organisation which requires human, financial and material resources for the purpose of achieving its goals and objectives. Every government owes its citizens basic secondary education as one of the social welfare services. The majority of governments however have not been able to meet the rising cost of education hence seeking alternative ways of funding education. This include diversity of funding sources and efficiency enhancing measures which are required to cover the significant financial investments for expanding access and improving the quality of secondary education (Yang, \& Yu, 2019).

Globally, there has been a realization of the need to ensure that schools have sufficient financial resources for smooth operations but most importantly to ensure that they meet their goals of positively impacting the economy by producing the required human resources (Banka, \& Bua, 2015). The importance of resources in the management of learning institutions cannot be underrated. It is not possible to deliver effective education without relevant resources. The difference made by availability and use of financial resources in schools is critical in improving the internal efficiency of education. Finance as a resource, plays a crucial role in the development of education (Singh, 2019). There are a wide variety of ways of financing educational investments. Governments which are sufficiently determined can devise strategies for shifting some of the financial burdens of education to individual students and their families through tuition fees or student loans, to employers through levies and payroll taxes or to local communities through self-help building or help with operation costs. In addition, they may devise taxes earmarked for education such as graduate or professionals surtax. All these are in realization of the fact that central government funding is not only or necessarily the most desirable way to finance education investments (Berhanu, 2018). Globally, there are a number of means and ways of creating resources for learning institutions. Such strategies encompass the prudent use of existing school financial resources and mobilizing even more for sustainability (Kingori, 2015).

Regionally, schools in Africa have been forced to develop financial resource mobilization strategies. These has been mainly due to the fact that Governments in Sub-Saharan Africa spend far 
much less on education financing than the developed nations yet about $15 \%$ of the school-age population lives in these countries. In some countries' like South Africa, Ghana and Zambia, public schools, tuition is free although students pay an entrance fee and buy uniforms. Most supplies are free and some students received government scholarships (Kisige \& Neema-Abooki, 2017). Clough, Fang, Vissa, and $\mathrm{Wu},(2019)$ however indicates that school principals in these regions face increasing administrative difficulties. These include inadequate and badly constructed buildings; shortage of books and equipment; lack of proper school furniture particularly desks; poor or sometimes non-existent maintenance and repairs; untrained and half-trained teachers who seldom stay long in the profession; over-crowded classrooms; poor communication and few supporting services especially health services. As a result, the administration of schools has become one of the most taxing jobs in the whole education system. In relation to the structure of physical facilities, Alhassan, Reddy and Duppati, (2019) indicated that the development efforts of schools have sometimes been frustrated because of lack of space for extension of the school, lack of housing for teachers and worse still, lack of essential facilities like desks, chalk, books, and so on. In Kenya, an analysis of the Kenyan government funding reveals that the education sector specifically in the secondary schools category still has large financial gaps which have not been met through government funding. According to Gill and Karakulah, (2019), to adequately fund Free Tuition Secondary Education (FTSE), extra resources away from general tax revenue need to be sought. A report by the Institute of Policy Analysis and Research (IPAR) in 2009 indicated that even with FTSE, schools still needed money for lunch, school infrastructure and boarding facilities. Further, households are also expected to provide nondiscretionary items such as school uniforms, sport kits, books and stationery. Accordingly, the institute did recommend that schools should establish localized fee waiver mechanisms and income generating activities. This situation has left secondary school principals in a dilemma. They therefore, have to be proactive and design financial resource mobilization strategies that would assist them cover for the deficits needed to ensure that the school operations continued. It was therefore against these background that the study sought to evaluate the financial resource mobilization strategies in secondary schools.

\section{Statement OF THE PROBlem}

In light of the one hundred percent transition that the government want to attain for students wishing to join secondary education, simply to maintain educational services at present levels will require a greater investment of resources in education (Gill, \& Karakulah, 2019). To expand educational services will require even more financial resources. Present levels of spending on education are already straining government budgets. In fact, in several cases it represents a huge chunk of government expenditure (King'athia, 2013). At the same time, the government revenues has reached a plateau due to slowed economic growth owing to foreign debts and other macro-economic problems affecting the Kenya (Kisige \& Neema-Abooki, 2017).

Despite the ministry of education efforts to train Principals on financial resource management it has been observed that the condition of teaching and learning have not improved much over the last two decades (King'athia, 2013). Ojwang (2026) did a study in Homabay on financial resource mobilisation strategies and internal efficiency of public secondary schools in Rachuonyo south sub-county. The finding was that retention rates had positive relationship with all the strategies in question a part from community funds which showed a negative relationship.

Wakoli and Kitainge (2019) did a study in Bungoma on relationship between financial resource mobilisation and internal efficiency of technical training institutions. The finding was that that there existed weak positive relationship between financial resource mobilization and internal efficiency of public training institutions. The reviewed studies focused much on the resource mobilization and internal efficiency of institutions but much investigation were not done on which strategy mobilized more funds. Therefore,this study explored strategies for resource mobilization in public secondary schools in Kapenguria Constituency, Kenya?

\section{RESEARCH DESIGN AND MEthodology}

The study adopted the cross sectional survey design. Simple random sampling was employed. The study used only the questionnaire to collect data. To test validity, expert opinion. The study used the test-retest method to establish the reliability of the items in the questionnaire.

\section{RESULTS}

The following were the results of the study,

\section{i School Fee Payment as a Financial Resource Mobilization Strategy}

The sought to establish extent to which school fees payment is a financial resource mobilization strategy in most schools in Kapenguria constituency. The study findings were presented in Table

\section{Table 1: Distribution Frequency of School Fee Payment as a Financial Resource Mobilization Strategy}

\begin{tabular}{|c|c|c|c|c|c|}
\hline Statements & & $\begin{array}{l}\text { Very } \\
\text { Large } \\
\text { extent }\end{array}$ & $\begin{array}{l}\text { Large } \\
\text { extent }\end{array}$ & $\begin{array}{l}\text { Small } \\
\text { extent }\end{array}$ & $\begin{array}{l}\text { No } \\
\text { extent } \\
\text { at all }\end{array}$ \\
\hline \multirow{2}{*}{$\begin{array}{l}\text { All the students } \\
\text { pay fee on time }\end{array}$} & $\mathrm{f}$ & 19 & 5 & 4 & 10 \\
\hline & $\%$ & 50 & 13.2 & 11 & 26 \\
\hline \multirow{2}{*}{$\begin{array}{l}\text { School fees is the } \\
\text { main source of } \\
\text { school income }\end{array}$} & $f$ & 28 & 4 & 2 & 2 \\
\hline & $\%$ & 74 & 11 & 5.3 & 5.3 \\
\hline \multirow{2}{*}{$\begin{array}{l}\text { The school fees } \\
\text { structure has costs } \\
\text { meant to cater for } \\
\text { all school } \\
\text { operations }\end{array}$} & $\mathrm{f}$ & 00 & 00 & 00 & 00 \\
\hline & $\%$ & 00 & 00 & 00 & 00 \\
\hline \multirow{3}{*}{$\begin{array}{l}\text { Total Fee } \\
\text { collected by the } \\
\text { school mostly is } \\
\text { sufficient }\end{array}$} & $\mathrm{f}$ & 2 & 1 & 00 & 2 \\
\hline & $\%$ & 5.3 & 2.6 & 00 & 5.3 \\
\hline & $\mathrm{f}$ & 27 & 3 & 1 & 7 \\
\hline
\end{tabular}




\begin{tabular}{|l|l|l|l|l|l|}
\hline $\begin{array}{l}\text { Students means } \\
\text { average fee } \\
\text { collected is much } \\
\text { higher }\end{array}$ & $\%$ & 71.1 & 7.8 & 2.6 & 18.42 \\
\hline
\end{tabular}

According to data presented in Table $1,19(50 \%)$ of the respondents reported that to a very large extent students pay school fees on time the reason attributed to the finding was that parents were aware of the importance of timely fee payment as it guarded against students disruption of studies. The finding was in line with that of Musavin, (2015) who established that nonpayment of school levies by parents negatively affected educational programs and school projects. $10(26 \%)$ of the respondents were of the were of the opinion that to no extent at all is fee paid in time. The meaning of the finding was that there were parents/guardians who were either unable to raise fees when the term began and therefore they staggered the payment or they never completed paying fees throughout the term. And this is the reason why other strategies of resources mobilization in schools come in hand to cater for deficit whenever fees levies are not sufficient. $28(74 \%)$ of the participants reported that to a very large extent fee payment is the main source of income in most schools. The indication of the finding is that if there is no timely fee payment by learners then there is like hood that running most programs in the school will be grounded. The finding agrees with that of Nyaga, (2015) who noted that there were delays in school fees payments in all the schools and that it had serious effects on the teaching and learning process. However, 2(5.3\%) of the participants reported that to no extent at all was fee payment a main source of income in schools. The finding is anchored on the report of the gazette notice of 2015 and 2017, the ministry of education recommended that the maximum cost of day schooling was Kenya shillings 22,244 while that of boarding schools was at Kenya shillings 66, 424 and Kenya shillings 69, 810 for special needs secondary schools. And thus this meant that school managers have to come up with some other strategies such as hiring the school buses, playgrounds and the main halls as shown in Table 1 so as to top up the deficit that is not catered for by the government. Most of the participants were of the opinion that the school fees structure has costs meant to cater for all school operations and perhaps this was the reason why other strategies for mobilizing resources were put in place so as to enable school managers get sufficient funds to run the schools throughout an academic year. As shown in Table1 (5.3\%) of the participants reported that to a very large extent total fee collected by the school mostly is sufficient and $00 \%$ of the respondent reported that the at no extent at all was fee collected sufficient to run schools' programs and hence the reason for mobilizing resources using other sources.

\section{ii Government Financial Intervention as a Financial Resource Mobilization Strategy}

The study sought to establish the extent to which government financial intervention is a financial resource mobilization strategy in public secondary schools in Kapenguria constituency, West Pokot County. The study findings were presented in Table 2

Table 2: Distribution Frequency of Government Financial Intervention as a Financial Resource Mobilization Strategy in Schools

\begin{tabular}{|c|c|c|c|c|c|}
\hline Statements & & $\begin{array}{l}\text { Very large } \\
\text { extent (1) }\end{array}$ & $\begin{array}{l}\text { Large } \\
\text { extent (2) }\end{array}$ & $\begin{array}{l}\text { Small } \\
\text { extent(3) }\end{array}$ & $\begin{array}{l}\text { No extent at } \\
\text { all (4) }\end{array}$ \\
\hline \multirow{2}{*}{$\begin{array}{l}\text { Free tuition allocations for students by the } \\
\text { government are timely and sufficient }\end{array}$} & $\mathrm{f}$ & 5 & 8 & 10 & 15 \\
\hline & $\%$ & 13.15 & 21.05 & 26.32 & 39.47 \\
\hline \multirow{2}{*}{$\begin{array}{l}\text { The government offers bursaries to needy } \\
\text { students in sufficient amounts boosting } \\
\text { school revenues }\end{array}$} & $\mathrm{f}$ & 22 & 10 & 6 & 00 \\
\hline & $\%$ & 57.89 & 26.32 & 15.78 & 00 \\
\hline \multirow{2}{*}{$\begin{array}{l}\text { cost sharing principal has helped the } \\
\text { institution grow its physical resource }\end{array}$} & $\mathrm{f}$ & 5 & 10 & 20 & 3 \\
\hline & $\%$ & $13 . .15$ & 13.89 & 52.63 & 7.9 \\
\hline \multirow{2}{*}{$\begin{array}{l}\text { Government allocations account form the } \\
\text { largest share of the schools budget }\end{array}$} & $\mathrm{f}$ & 30 & 2 & 3 & 3 \\
\hline & $\%$ & 78.94 & 5.26 & 7.9 & 7.9 \\
\hline \multirow{2}{*}{$\begin{array}{l}\text { Government financial interventions are the } \\
\text { only revenues by the school }\end{array}$} & $\mathrm{f}$ & 1 & 1 & 10 & 26 \\
\hline & $\%$ & 2.63 & 2.63 & 26.32 & 68.42 \\
\hline
\end{tabular}

Data presented in Table 2 show that $15(39.47 \%)$ of participant and $10(26.32 \%)$ of the participants were of the opinion that to a small extent free tuition allocation for students by the government are timely and sufficient. The finding meant that there government financial interventions do not cater for all the needs of the schools. The reasons include; delays in release of government financial interventions and the insufficiency that might result from reliance on such financial resource. Free Tuition Secondary Education were inadequate and delayed before disbursement. Sometimes due to bureaucracies in the processing of the funds, delays are experienced causing panic and outcry among the school stakeholders. The Kenya budget to education is comparatively large yet seems to be inadequate requiring consolidated support for sustainability. And thus the reason for other resources which school managers put in place in order to realize sustainability. The finding was in agreement with that of Wanjala and Hussein, (2017) who had established that even after the introduction of subsidized fee the enrollments rates remained 
low, because finances to support Free Tuition Secondary Education were inadequate and delayed before disbursement. Further the same authors had established that, the implementation of subsidized fees programme by the government of Kenya has not greatly influenced access to quality education in public secondary schools. $13(43.20 \%)$ of the participants to a large extent felt that Free tuition allocations for students by the government are timely and sufficient. The reason that was attached to the finding was that the participants were representing the schools which had been in existence for over 20 years and therefore they had developed in terms of structure and therefore the financial aid that they received from the Ministry of Education seemed to be enough.

According to the data presented in Table 2, 22(55.89\%) of participants agreed that to a very large extent the government offers bursaries to needy students in sufficient amounts boosting school revenues. The implication of the finding is that bursaries are one of the resources that finance the running of the schools. But $00(00 \%)$ of the participants reported that to no extent at all are bursaries sufficient to boost school revenues. The meaning of the finding is that there are some students who do not receive perhaps because they are not needy and therefore the schools in which such students are in have not realized the importance of the bursaries.
The other reason which can be attached to the finding is that there are rising demands for educational requirements and it is marred with a lot of irregularities ranging from delays in disbursement by the government to biased allocation by the constituency bursary committees. Indeed political interference has compromised equity considerations in award of bursaries. While the poor who are not able to afford the extra charges in schools are denied the fund, some rich, politically connected individuals are awarded the bursaries or they influence award to some of their relatives. The finding contradicts with that of Commonwealth (2016) which states that the needy children should be awarded scholarship, bursaries and other mechanisms laid down so as to boost their education in various learning levels.

iii Community Resource Mobilization as a Financial Resource Mobilization strategy

The study sought to evaluate extent to which community resource mobilization is a financial resource mobilization strategy in Kapenguria constituency, West Pokot County. The study findings were presented in Table 3 .

\section{Table 3: Distribution Frequency of Community Resource Mobilization as a Financial Resource Mobilization strategy}

\begin{tabular}{|c|c|c|c|c|}
\hline Statements & $\begin{array}{l}\text { Very } \\
\text { large } \\
\text { extent (1) }\end{array}$ & $\begin{array}{l}\text { Large } \\
\text { extent(2) }\end{array}$ & $\begin{array}{l}\text { Small } \\
\text { extent(3) }\end{array}$ & $\begin{array}{l}\text { No } \\
\text { extent at } \\
\text { all (4) }\end{array}$ \\
\hline \multirow{2}{*}{$\begin{array}{l}\text { NGOs frequently fund } \\
\text { development in the } \\
\text { school }\end{array}$} & f 1 & 1 & 00 & 36 \\
\hline & $\% 2.6$ & 2.6 & 00 & 94.73 \\
\hline \multirow{2}{*}{$\begin{array}{l}\text { CDF allocations has } \\
\text { been instrumental to } \\
\text { develop the school }\end{array}$} & $\begin{array}{ll}\mathrm{f} & 30\end{array}$ & 4 & 00 & 4 \\
\hline & $\% 78.94$ & 10.52 & 00 & 10.52 \\
\hline \multirow{2}{*}{$\begin{array}{l}\text { Old boys of the schools } \\
\text { often support } \\
\text { development projects }\end{array}$} & f 10 & 5 & 3 & 20 \\
\hline & $\% 26.31$ & 13.15 & 7.9 & 52.63 \\
\hline \multirow{2}{*}{$\begin{array}{l}\text { The school has } \\
\text { conducted harambee to } \\
\text { support development }\end{array}$} & f 5 & 25 & 3 & 5 \\
\hline & $\% 13.15$ & 65.78 & 7.9 & 13.15 \\
\hline \multirow{2}{*}{$\begin{array}{l}\text { Well-wishers provide } \\
\text { development funds to } \\
\text { the school }\end{array}$} & f 2 & 1 & 5 & 30 \\
\hline & $\% 5.26$ & 2.63 & 13.15 & 78.94 \\
\hline
\end{tabular}

Community resource mobilization is the process of engaging communities to identify community priorities, resources, needs and solutions to schools in such a way as to promote development in schools. According to data presented in Table 3, $36(94.73 \%)$ of the participants reported that to no extent at all do NGOs frequently fund development in the school. This finding meant that within the area where the study was conducted the NGOS are not based there and therefore, they do not part of the community partners who fund the schools. Another meaning to the finding is that could be there are NGOS around the area but there is nobody influential around the area of study who can do a proposal requesting them to fund some structures in the schools. However, $1(2.6 \%)$ of the participants reported that to a very large extent NGOS frequently fund development in the school. The finding meant that even though the NGOS fund schools, to a small extent their contribution is not significant in most schools.

$30(78.94 \%)$ of participant were to a very large extent that CDF allocations has been instrumental to develop the schools because $\mathrm{CDF}$ is a form of subsidy that assists in bridging the investment gap left by poor parents and guardians. According to CDF Act of 2003, Constituency Development Fund was intended to improve on access to secondary education through creating capacity for improved enrolment and to ensure transition and completion rates through provision of bursary to needy students and education takes the lion's share of the total allocations from CDF. However, $4(10.52 \%)$ of the participants reported that to a small extent were CDF allocations has been instrumental to develop the schools. The meaning of the finding is that $\mathrm{CDF}$ allocations to schools in some 
parts of Kapenguria constituency is marred with more hurdles for instance favoritism during allocation or even misappropriation by the in charge.

$20(52.63 \%)$ of the participants were of the view that to no extent at all do old boys of the schools often support development projects. The meaning of the finding was that the act of humanity is totally not a common practice among the alumni of the schools. But, $5(13.15 \%)$ of the participants reported that to a very large extent old boys of the schools often support development projects. The meaning of the finding would be that these old boys understand are aware that education is fundamental to development of any society and thus supporting it to thrive is key. Another meaning of the finding is that, would be the old boys were supported by guardians during their various stages of learning and therefore they feel they have a moral obligation to give back to society. The other meaning of the finding is that some old boys partner with their local community so that alumni can provide assistance to the area while also having the opportunity to build relationships with community members and leaders. The other reason would be that some old boys often want to stay connected to their alma mater and help future generations of alumni have the same opportunities and positive experiences they did while they were in schools. Banka and Bua, (2015) contradicted this results by noting that Old Students Associations se contribution to school recruitment of teachers and maintenance of students ${ }^{\text {ee }}$ discipline significantly affect secondary school management.

$25(65.78 \%)$ of participants were of the opinion that to a large extent schools have conducted harambees to raise funds. The meaning adduced from the finding is that the Harambee movement is a unique way of financing education in Kenya since the independence period to the present. Harambee movement achieved a different dimension with the introduction of University fees payment in July, 1991. The reason why perhaps harambees are held is because the community understands that working together for a common good is better and it also demonstrates that the community members indeed own and they are proud of their schools. Data in Table 3 show that $30(78.84 \%)$ of the participants were of the opinion that to no extent at all do

Well-wishers provide development funds to the school. The finding might mean that no free money is donated to schools by people who no interest in the schools. Or the other meaning of the finding would be that community members have not been mobilized to help in developing the schools. Ngeiywa, (2016) contradicted this results by noting that church donors have really developed secondary schools infrastructure. The meaning of the finding is that well-wishers, donors and other community initiatives is hard to come by owing to the hardships that already exist in the region. This could be a reason why the community efforts might direct their efforts to other initiatives such as food programs as opposed to school programs. The region also is located in the semi -arid areas of Kenya and hence might be miles away from the major urban areas of the country from where they can attract help from major donors.

Other reasons might include the inability of the principals in the region to develop initiatives to attract community resources for example attracting donors in the region to fund school infrastructure. The principals need to develop skills to attract community resources. This will ensure that the community resources such as donors get to know the needs of the schools and as a result will be able to contribute to the development of the school. Donor funding for example by the church influence students sponsorship mainly those who are bright and from humble background.

\section{iv Income Generating Activities as Financial Resource Mobilization Strategy}

The study sought to establish the extent to which income generating activities is a financial resource mobilization strategy in Kapenguria constituency, West Pokot County. The study findings were presented in Table 4

\section{Table 4: Distribution Frequency of Income Generating Activities as Financial Resource Mobilization Strategy}

\begin{tabular}{|c|c|c|c|c|c|}
\hline Statements & & $\begin{array}{l}\text { Very large } \\
\text { extent(1) }\end{array}$ & $\begin{array}{l}\text { Large } \\
\text { extent } \\
(2)\end{array}$ & $\begin{array}{l}\text { Small } \\
\text { extent(3) }\end{array}$ & $\begin{array}{l}\text { No } \\
\text { extent at } \\
\text { all (4) }\end{array}$ \\
\hline \multirow{2}{*}{$\begin{array}{l}\text { The school hires some of its } \\
\text { physical resources to } \\
\text { outsiders }\end{array}$} & $\mathrm{f}$ & 36 & 2 & 00 & 00 \\
\hline & $\%$ & 94.74 & 5.26 & 00 & 00 \\
\hline \multirow{2}{*}{$\begin{array}{l}\text { The school farm products } \\
\text { supplement the school } \\
\text { budgets }\end{array}$} & $\mathrm{f}$ & 2 & 1 & 00 & 33 \\
\hline & $\%$ & 5.26 & 2.63 & 00 & 86.84 \\
\hline \multirow{2}{*}{$\begin{array}{l}\text { The schools offers services } \\
\text { such as printing and } \\
\text { photocopy to outsiders }\end{array}$} & $f$ & 5 & 2 & 1 & 30 \\
\hline & $\%$ & 13.15 & 5.26 & 2.63 & 78.94 \\
\hline \multirow{2}{*}{$\begin{array}{l}\text { Teachers living in the } \\
\text { school pay for rent }\end{array}$} & $\mathrm{f}$ & 26 & 7 & 1 & 1 \\
\hline & $\%$ & 68.42 & 18.42 & 2.63 & 2.63 \\
\hline \multirow{2}{*}{$\begin{array}{l}\text { School kitchen provides } \\
\text { catering services }\end{array}$} & $\mathrm{f}$ & 15 & 8 & 10 & 2 \\
\hline & $\%$ & 39.47 & 21.05 & 26.32 & 5.26 \\
\hline
\end{tabular}


Odundo and Rambo (2013) emphasizes on the importance learning institutions coming up with of income generating activities. As shown in the Table 4, 36(94.7\% ) of the participant were of the view that to a large extent the schools hire some of its physical resources to outsiders. The meaning of the finding is that the managers of the schools out source for funds to help them run their schools. The other meaning of the finding is that the schools that hire the physical facilities such as buses and playground as shown in Table 1 are those ones that are developed in terms of structure and could be they sit at an area of above five acres. $33(86.84 \%)$ of the participants reported that to no extent at all do the school farms products supplement the schools' budget. The reason why the finding is so is because most schools in the constituency sit on small hectares of land and therefore, farming activities may not be that vibrant. The other reason which may be attached to the finding would be that the constituency is located in an arid area in Kenya and perhaps that is why farming is not possible.

$30(78.94 \%)$ of the respondent reported that to no extent at all do the schools offers services such as printing and photocopy to outsiders. The meaning of the finding would be that if the services are extended to the outer community of the schools, the schools will be deemed to be business hubs and this will be a threat to the security of the students and as well it will disrupt learning and other activities in the school. The finding contradicted King'athia, (2013) who revealed that that income generating activities which could have eased the burden of educational financing were not fully exploited by school managers. It concluded that most principals lacked entrepreneurial and business skills to exploit income generating activities as an alternative source of education financing to promote students retention. $26(68.42 \%)$ of the participants reported that teachers living in the schools' houses pay rent. The meaning of the finding is that teachers are paid an enhanced house allowance and therefore, they cannot be housed the schools freely. The other meaning of the finding is that school houses is an income generating activity and pay rent means compliance. $23(60.52 \%)$ as shown in Table 4 most of the respondent reported that school kitchen provides catering services. The meaning meant that during school holidays and weekends they engage themselves in sourcing for funds which is a good idea.

\section{RECOMMENDATION OF THE STUDY}

From the findings and conclusions of the study the following recommendations were made;

\section{i)Community leaders and Parents}

It was recommended that the community leaders should mobilize parents /guardians, church leaders on the importance of assisting schools with finances so as to enable them develop infrastructure. There is also an urgent need to educate members of the community the importance and role of Harambee .

\section{ii)County Directors of Education}

There is need for this stakeholder to raise awareness amongst principals and teachers on the need to come up with projects which are not labour intensive so as to assist school raise funds.

\section{iii)Ministry of finance}

There is need for the Ministry of finance to increase capitation to each student since from the findings it was realized that fee payment is the major source of resource mobilization in schools.

\section{REFERENCES}

[1] Alhassan, A., Li, L., Reddy, K., \& Duppati, G. (2019). The impact of formal financial inclusion on informal financial intermediation and cash preference: evidence from Africa. Applied Economics, 51,4597-4614

[2] Al-Samarrai, S., Cerdan-Infantes, P., \& Lehe, J. D. (2019). Mobilizing Resources for Education and Improving Spending Effectiveness: Establishing Realistic Benchmarks Based on Past Trends. The World Bank

[3] Amos, O., \& Koda, G. M. (2018). Contribution of school-based incomegenerating activities in quality education provision in secondary schools managed by the Catholic Diocese of Moshi, Tanzania. British Journal of Education, 6, 49-69.

[4] Banka, N., \& Bua, T. (2015). Impact of Old Students' Associations on the management of Secondary Schools in Zone B Senatorial District of Benue State. International Journal of Innovative Education Research, 3, 35-45.

[5] Berhanu, T. (2018). Practice and Challenges of Financial Resource Management in Haddiya Zone Public Secondary Schools .Doctoral dissertation, Addis Ababa University, Nigeira

[6] Chweya, M. (2015). The impact of cost sharing policy in education on the dropout rates of public secondary schools in Keumbu division, Kisii central district. Doctoral dissertation,Kissi University Kenya.

[7] Clough, D. R., Fang, T. P., Vissa, B., \& Wu, A. (2019). Turning lead into gold: how do entrepreneurs mobilize resources to exploit opportunities?. Academy of Management Annals, 13(1), 240-271

[8] Emana, B. (2019). Practice and Challenges of Financial Resource Mobilization and Utilization in Government Primary Schools Chalia Woreda, West Shoa Zone, Oromia.Doctoral dissertation, Addis Ababa University,Nigeria.

[9] Gill, I. S., \& Karakulah, K. (2019). Has Africa Missed the Bus? The Confusing Consensus about the Continent's Growth

[10] Kiarie, B., Gesimba, P., \& Mwaura, P. (2019). Examining the Effects of Income Generating Activities on Physical Infrastructural Development among Public High Schools in Molo Sub-County of Nakuru County, Kenya.

[11] King'athia, D. G. (2013). Income generating activities and students' retention Rates in public secondary schools in Ng'arua Division Of Nyahururu District. Laikipia County (Doctoral dissertation, Mount Kenya University).

[12] Kingori, J. N. (2015). Influence of hidden costs in education on students 'participation in public secondary schools in Kikuyu Sub County, Kenya.

[13] Kisige, A., \& Neema-Abooki, P. (2017). Financial Resource Mobilization Projects and its Relationship to Academic Staff Commitment in Kenya.

[14] Musavin, M. G. W. (2015). Teachers' perceptions on school dropout among upper Trans-Nzoia East, Trans.

[15] Ngeiywa, A. (2016). Influence of donor funding on development of secondary education: a case of church sponsored schools in West Pokot County, Kenya.

[16] Nyaga, B. M. (2015). Effects of delayed fees payments on the teaching and learning process in public secondary schools in Mbeere District, Kenya. Unpublished MEd Thesis, Nairobi: Kenyatta University.

[17] Obwari, H. N. (2013). Influence of constituency development fund on education development in the counties: a study of public secondary schools in likuyani constituency, kakamega county, Kenya.Doctoral dissertation, University of Nairobi.Kenya.

[18] Odundo, P. A., \& Rambo, C. M. (2013). Effect of School-Based Income Generating Activities on the Financial Performance of Public Secondary Schools in Kenya. Chinese Business Review, 12.

[19] Onuko, J. A. (2013). Impact of bursary schemes on retention of students in public secondary schools in Gem district, Kenya .Doctoral dissertation, The University of Nairobi,Kenya.

[20] Singh, S. (2019). Financing of school education in Punjab adequacy equity and efficiency 
[21] Wanjala, G., \& Hussein, A. K. (2017). Impact of Subsidised Fees on Students' Access to Quality Education in Public Secondary Schools in Wajir County, Kenya.

[22] Yang, Y., \& Yu, G. (2019). The analysis of social resource mobilization on new media: A case study of Chinese environmental protection documentary Under the Dome. Telematics and Informatics, 37, 128-136.

\section{AUTHORS}

First Author - Millicent Cherotich

Second Author - Rose Atoni corresponding author rose.atoni@yahoo.com

Third Author - Jennifer Munyua jmunyua @gmail.com 